\title{
Hg Concentrations in Muscles and Gills of Fish from Shallow Lakes of Different Trophic Status (Eastern Poland)
}

\author{
Jacek Rechulicz ${ }^{1 *}$, Agnieszka Chałabis-Mazurek², Jose Luis Valverde Piedra ${ }^{2}$, \\ Tomasz Mieczan ${ }^{1}$ \\ ${ }^{1}$ Department of Hydrobiology and Protection of Ecosystems, University of Life Sciences in Lublin, Lublin, Poland \\ ${ }^{2}$ Sub-Department of Pharmacology, Toxicology, and Environmental Protection, Department of Preclinical \\ Veterinary Sciences, University of Life Science in Lublin, Lublin, Poland
}

Received: 21 December 2017

Accepted: 24 January 2018

\begin{abstract}
Fish are a group of organisms that are highly sensitive to mercury $(\mathrm{Hg})$ contamination of the aquatic environment. At the same time, because this element can be accumulated in tissues, it can pose a serious threat to human health. The main objective of the study was to determine the content of $\mathrm{Hg}$ in the muscles $(\mathrm{HgM})$ and gills $(\mathrm{HgG})$ of various species of fish from shallow lakes with varied physicochemical conditions. Sampling was done in 5 lakes from April to November 2012 and 2013. The concentration of $\mathrm{Hg}$ in fish tissues was affected by 4 variables, including ammonium nitrogen, chlorophyll-a, oxygen saturation, and temperature, and the first 2 axes explained 78.9\% of total variance in $\mathrm{Hg}$ concentration. The concentration of $\mathrm{Hg}$ in muscles was widely varied depending on the fish species, and its highest concentration was observed in predatory fish such as asp and perch, while the lowest concentration of this element was found in Prussian carp, bream, and rudd. Although content of $\mathrm{Hg}$ increased with fish body length, in non-predatory fish this correlation was less clear. The gills of the fish contained lower concentrations of $\mathrm{Hg}$ than the muscles. $\mathrm{Hg}$ content in muscles was within acceptable weekly limits, but predatory fish consumed in large quantities by the local population may pose a potential risk for human health.
\end{abstract}

Keywords: Hg, eutrophication, lakes, fish tissues

\section{Introduction}

Mercury (Hg), due to its widespread occurrence and high geochemical and biochemical activity, is one of the most dangerous global environmental contaminants. Due to its high accumulation, it can easily be introduced into the food chain, posing a significant toxicological threat to the health of humans and animals. All forms of $\mathrm{Hg}$, and in particular organic compounds with a short carbon chain, are toxic for aquatic organisms. The toxic effect of $\mathrm{Hg}$ on living organisms consist in its high affinity for sulfhydryl groups of proteins and enzymes and inhibition of their biochemical functions [1].

*e-mail: jacek.rechulicz@up.lublin.pl 
$\mathrm{Hg}$ and its compounds become included in various natural cycles and are thus disseminated in the natural environment. The course of the biogeochemical cycle of $\mathrm{Hg}$ in the aquatic environment depends on its concentration and largely on physicochemical reactions determining its form of occurrence, which depend on external factors such as temperature, $\mathrm{pH}$, availability of oxygen and light, organic carbon content, the presence of microorganisms, or the effect of other chemical compounds [2-6]. In the water this element can appear as elemental $\mathrm{Hg}$ or in the form of inorganic or organic compounds. Due to the very low solubility of $\mathrm{Hg}$ salts in water, the element sediments with suspended matter to the bottom sediment, in which it is strongly bound and undergoes methylation processes. However, as a result of chemical reactions and under the influence of biological factors, $\mathrm{Hg}$ adsorbed in sediment may easily become remobilized, thereby creating a threat for living organisms. Hg compounds pass through successive links of the food chain, beginning with plankton and plants, through herbivorous organisms, and finally to predators [7]. This is a key stage in the transport of $\mathrm{Hg}$, in which it leaves the water in the form of contaminated organisms such as shellfish, crustaceans, and fish, many of which are food products. Fish are the most significant bioindicator of $\mathrm{Hg}$ contamination of the aquatic environment. A study by Wałkuska et al. [8] showed that in an aquatic environment even slightly contaminated by $\mathrm{Hg}$, fish accumulate significant amounts of the element in their bodies. $\mathrm{Hg}$ in fish is mainly absorbed through the digestive tract, gills, and to a lesser degree the skin [9-11].

Previous studies of $\mathrm{Hg}$ content in fish have mainly dealt with Scandinavian ecosystems [12-14], marine environments [15-16] or the large ecosystems of American and African lakes [17-21]. Considerably fewer studies have dealt with $\mathrm{Hg}$ contamination of fish in shallow lakes in the temperate zone [22]. Only a few of these have taken into account the effect of fish size and trophic group on the content of this element in tissues [23-25].

The presence of $\mathrm{Hg}$ in the aquatic ecosystem may pose a threat to human health associated with the consumption of methyl $\mathrm{Hg}$ contained in fish, whose biological half-life is a few hundred days [26]. It seems that in lake districts used by the local population (including those located in the temperate zone), it may pose a potential threat to human health as a consequence of consumption of fish caught commercially or recreationally.

The main objective of the study was to determine the content of $\mathrm{Hg}$ in the tissues (muscles and gills) of fish in shallow lakes with varied physicochemical properties. On the basis of the biological and physicochemical data collected, we attempted to verify the hypothesis that the trophic status of shallow lakes could have an impact on the content of $\mathrm{Hg}$ in the tissues of fish of various sizes and from various trophic levels.

\section{Material and Methods}

\author{
Study Area
}

The study area comprised 5 shallow (mean depth less than $2.5 \mathrm{~m}$ ), polymictic reservoirs (eutrophic: Dratów, Białe Sosnowickie, Domaszne, Czarne Sosnowickie, and hypertrophic lake Syczyńskie) in the Polesie Lubelskie region of eastern Poland. More than $70-80 \%$ of the lakes' catchments are used for agricultural purposes (mostly arable lands and meadows). In 1961 Dratów, Białe Sosnowickie, Domaszne, and Czarne Sosnowickie lakes were connected with the Wieprz-Krzna Canal (W-KC). Additionally, in the zone of W-KC, 10 lakes were transformed into storage reservoirs. As a result of feeding with canal waters, the rate of water exchange in the lakes increased and its quality and trophic condition improved. The hydrotechnological facilities are efficient, carefully maintained and failure-free. The waters in the reservoirs are exchanged several times in a hydrological year, irrespective of the natural feeding system. Studied reservoirs are characterized by permanent and longlasting blooms of cyanophyte. Emergent vegetation is dominated by common reed (Phragmites australis (Cav.) Trin. ex Steud.), bulrush (Schoenoplectus lacustris (L.) Palla), and broadleaf cattail (Typha latifolia L.). Submerged vegetation is limited to very small, single stands of rigid hornwort (Ceratophyllum demersum L.) and sago pondweed (Stuckenia pectinata L.). Lake Syczyńskie was characterized by intensive development of emergent vegetation, dominated by reed (Phragmites communis Trin.) and temporal blooms of Planktothrix agardhii (Gomont).

\section{Analysis of Physical and Chemical Parameters of Water}

The water samples for chemical analysis were taken from littoral and pelagial studied lakes on a monthly basis from April to November 2012 and 2013. The following physical and chemical factors were examined: temperature, $\mathrm{pH}$, conductivity, total organic carbon (TOC), chlorophyll $a$, ammonium-nitrogen, nitratenitrogen, and phosphates. Temperature, conductivity, and $\mathrm{pH}$ were recorded in situ using a multiparametric probe (YSI 556, USA). Total organic carbon was determined using the multiparametric UV analyzer (Secomam, France), and the remaining factors were analyzed in the laboratory. Chlorophyll $a$ was determined by spectrophotometric analysis of the acetone extract of the algae. $\mathrm{Hg}$ concentration in the bottom sediments were stored in a refrigerator at $0-6^{\circ} \mathrm{C}$ and then weighed and inserted into the Hg/MA-2000 system (NIC, Japan). In order to remove any interfering substances (generated during thermal decomposition of a sample, resulting in adverse affect measurements), gas washing was performed. Total $\mathrm{Hg}$ content was calculated based on $1 \mathrm{~kg}$ dry mass of sediments. 
Fish Sampling and Data Analysis

For analysis of content of total $\mathrm{Hg}$ in muscles (HgM) and gills $(\mathrm{HgG})$, fish were purchased from local fishermen who conducted fish harvesting in five lakes using multimesh gillnets (our study was carried out in accordance with the criteria outlined in the guiding principles of the European Community Council Directive for the Care and Use of Animals).

All caught fish were determined for species, total length (TL, in $\mathrm{cm}$ ), and body mass (W, in $\mathrm{g}$ ).

The caught fish were divided according to 2 criteria: total length of fish (TL) and trophic groups. In term of the total length the 2 size classes were $\mathrm{TL}<20 \mathrm{~cm}$ and $\mathrm{TL}>20 \mathrm{~cm}$, while the terms by trophic groups - predatory (P) (pike, pikeperch, and perch with $\mathrm{TL}>14 \mathrm{~cm}$ ) and other non-predatory fish (NP) - were determined. Muscle and gill samples were taken from fish and kept frozen $\left(-20^{\circ} \mathrm{C}\right)$ until analysis.

The analysis of the content of $\mathrm{Hg}$ was carried out in a total of 180 fish from 5 studied lakes, among them 26 individuals of predatory fish and 154 individuals of nonpredatory fish.

\section{Analysis of $\mathrm{Hg}$ Content in Muscles and Gills}

Samples of fish muscles and gills were immediately deep-frozen, freeze-dried (lyophilized), and homogenized. Homogenized samples were stored in a refrigerator at $0-6^{\circ} \mathrm{C}$ and then weighed and inserted into the Hg/MA-2000 system (NIC, Japan). In order to remove any interfering substances (generated during thermal decomposition of a sample, resulting in adversely affecting measurements), gas washing was performed. Total $\mathrm{Hg}$ content was calculated based on wet tissue mass.

\section{Statistical Analysis}

Normality of the data was assessed by a ShapiroWilk test, and homogeneity of variance by Bartlett's test. Because data were skewed, log transformations were applied to attain normal distributions and homogenous variances. Differences among species, lakes, trophic groups, and size class of fish were assessed by analysis of variance with log-transformed data, and between specific sites by HSD Tukey's post hoc test. Differences in $\mathrm{Hg}$ concentration of $\mathrm{Hg}$ in the fish tissues (muscles and gills) was determined using a t-test. The changes of $\mathrm{Hg}$ concentration in tissue of fish from different trophic groups and different size classes using the regression analysis were determined. All analysis was performed at a significance level of $p \leq 0.05$.

Detrended correspondence analysis (DCA) was used to measure and illustrate the variability gradient indicated by the fish. Because the length of the gradient was $<2$, redundancy analysis (RDA) was used to determine the variables that best predicted the distribution of fish and $\mathrm{Hg}$ concentration in their tissues. The set of environmental variables was reduced to a few orthogonal axes as composite environmental gradients structuring distribution patterns. Stepwise forward selection was used to include significant variables $(p<0.05)$ in the model. Automatic forward selection of environmental

Table 1. Physical and chemical parameters of water and concentration of $\mathrm{Hg}$ in the bottom sediments in the lakes studied (mean $2012-$ $2013 \pm$ SD); SD - standard deviation.

\begin{tabular}{|c|c|c|c|c|c|c|}
\hline \multirow{2}{*}{ Parameters } & \multirow{2}{*}{ Unit } & Dratów & Białe Sosnowickie & Domaszne & Syczyńskie & Czarne Sosnowickie \\
\hline & & Mean \pm SD & Mean \pm SD & Mean \pm SD & Mean \pm SD & Mean \pm SD \\
\hline Temperature & ${ }^{\circ} \mathrm{C}$ & $16.3 \pm 5.4$ & $17.1 \pm 5.6$ & $17.4 \pm 6.5$ & $15.8 \pm 9.9$ & $17.4 \pm 6.0$ \\
\hline $\mathrm{pH}$ & $\mathrm{pH}$ & $8.32 \pm 0.31$ & $8.12 \pm 0.10$ & $7.41 \pm 0.98$ & $7.94 \pm 0.61$ & $7.44 \pm 0.25$ \\
\hline Conductivity & $\mu \mathrm{S} \mathrm{cm}^{-1}$ & $128 \pm 22$ & $183 \pm 9$ & $188 \pm 19$ & $492 \pm 95$ & $149 \pm 14$ \\
\hline Oxygen & $\mathrm{mg} \mathrm{O}_{2} \mathrm{~L}^{-1}$ & $10.65 \pm 0.56$ & $11.34 \pm 0.42$ & $9.53 \pm 0.95$ & $11.69 \pm 3.28$ & $7.20 \pm 2.37$ \\
\hline $\mathrm{N}-\mathrm{NH}_{4}$ & $\mathrm{mg} \mathrm{NH}_{4} \mathrm{~L}^{-1}$ & $0.085 \pm 0.069$ & $0.168 \pm 0.082$ & $0.134 \pm 0.063$ & $0.548 \pm 0.283$ & $0.835 \pm 0.095$ \\
\hline $\mathrm{N}-\mathrm{NO}_{3}$ & $\mathrm{mg} \mathrm{NO}_{3} \mathrm{~L}^{-1}$ & $0.096 \pm 0.112$ & $0.138 \pm 0.048$ & $0.057 \pm 0.025$ & $0.185 \pm 0.238$ & $0.636 \pm 0.202$ \\
\hline $\mathrm{P}-\mathrm{PO}_{4}^{3-}$ & $\mathrm{mg} \mathrm{PO}_{4}{ }^{3-} \mathrm{L}^{-1}$ & $0.024 \pm 0.020$ & $0.037 \pm 0.032$ & $0.058 \pm 0.060$ & $0.232 \pm 0.185$ & $0.037 \pm 0.031$ \\
\hline$P_{\text {tot }}$ & $\mathrm{mg} \mathrm{P} \mathrm{L} \mathrm{L}^{-1}$ & $0.191 \pm 0.010$ & $0.256 \pm 0.118$ & $0.242 \pm 0.066$ & $0.499 \pm 0.098$ & $0.146 \pm 0.057$ \\
\hline Chlorophyll $a$ & $\mathrm{mg} \mathrm{L}^{-1}$ & $79.06 \pm 41.64$ & $55.18 \pm 4.87$ & $29.76 \pm 14.93$ & $73.84 \pm 39.24$ & $14.52 \pm 10.01$ \\
\hline TOC & $\operatorname{mg~C~L}{ }^{-1}$ & $6.7 \pm 0.7$ & $6.3 \pm 0.9$ & $4.3 \pm 0.1$ & $7.1 \pm 1.4$ & $24.5 \pm 4.9$ \\
\hline $\mathrm{Hg}$ & $\begin{array}{c}\text { mg kg-1 dry mass } \\
\text { of bottom } \\
\text { sediments }\end{array}$ & $0.0062 \pm 0.0001$ & $0.0078 \pm 0.0001$ & $0.0062 \pm 0.0002$ & $0.0012 \pm 0.0002$ & $0.0211 \pm 0.0001$ \\
\hline
\end{tabular}




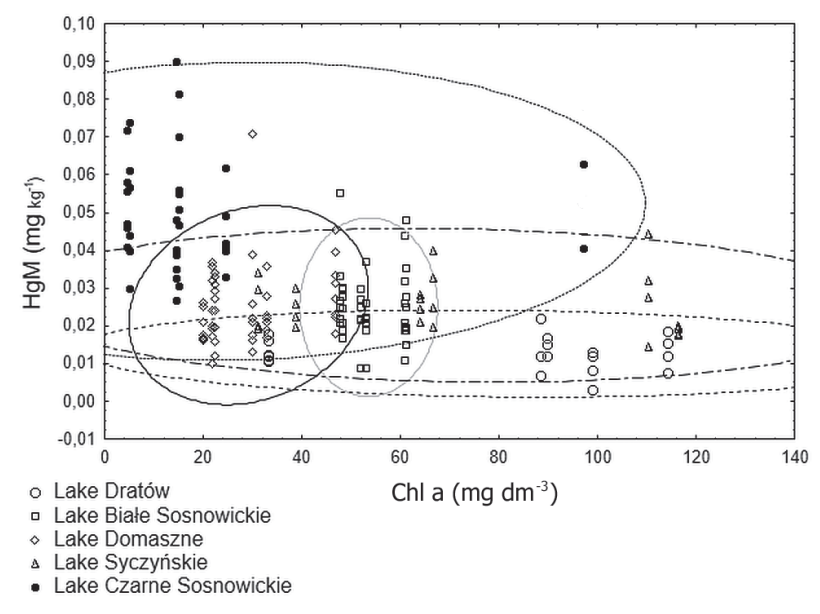

Fig. 1. The relationship between mercury concentration in fish muscles $\left(\mathrm{HgM}\right.$ in $\left.\mathrm{mg} \cdot \mathrm{kg}^{-1}\right)$ and chlorophyll a concentration $\left(\mathrm{Chl} a\right.$ in $\left.\mathrm{mg} \mathrm{dm}^{-3}\right)$ in water from studied lakes.

variables and the Monte Carlo permutation test (999 permutations) were used to determine the most important variables. The proportion of variance explained by the environmental variables was quantified using variance partitioning. Ordination analyses were performed by means of CANOCO 4.5 for Windows.

\section{Results}

\section{Physical and Chemical parameters of Water}

The water temperature varied among reservoirs, ranging from $15.8^{\circ} \mathrm{C}$ in Lake Syczyńskie to $17.4^{\circ} \mathrm{C}$ in Czarne Sosnowickie. Differences among the studied reservoirs were found for conductivity, $\mathrm{P}_{\text {tot }}, \mathrm{N}_{-} \mathrm{NH}_{4}$,
$\mathrm{P}^{-} \mathrm{PO}_{4}$, contents of chlorophyll $a$, and $\mathrm{Hg}$. Although conductivity, concentrations of $\mathrm{P}_{\text {tot }}$, and $\mathrm{P}_{-} \mathrm{PO}_{4}$ were highest in Syczyńskie, the remaining parameters (chlorophyll $a, \mathrm{~N}^{-\mathrm{NH}_{4}}$, TOC, and $\mathrm{Hg}$ ) showed highest values in lakes Dratów, Białe Sosnowickie, and/or Czarne Sosnowickie (Table 1).

\section{Concentration of $\mathrm{Hg}$ in Fish: General Results}

The Hg concentration in fish muscle was dependent ( $>0.05)$ on trophy of lakes expressed by chlorophyll a. Fish from Czarne Sosnowickie had the highest concentration of $\mathrm{Hg}$ in muscle, and according to the amount of increasing chlorophyll $a$ in the lake, the $\mathrm{Hg}$ concentration in fish tissues decreased (Fig. 1). From 10 analyzed fish species found in the investigated lakes the 4 belonged to predatory species (i.e., perch, pike, pikeperch, and asp) and 6 species belonged to nonpredatory fish (i.e., roach, Prussian carp, bream, silver bream, rudd, and brown bullhead). Analysis of the results showed that the $\mathrm{Hg}$ concentrations in both tissues of fish - muscle ( $\mathrm{HgM})$ and gills $(\mathrm{HgG})$ - were dependent on the studied lake $(\operatorname{HgM}$, ANOVA F $(4,165)=62.22$, $\mathrm{p}<0.0001 ; \mathrm{HgG}$ ANOVA, $\mathrm{F}(4,175)=21.54, \mathrm{p}<0.0001)$. Simultaneously, its contents in the gills of all fish species was significantly lower (t-test, $\mathrm{t}=13.81$, $\mathrm{df}=358$, $\mathrm{p}<0.001$; Table 2). A significant dependence $(\mathrm{p}<0.001)$ of $\mathrm{Hg}$ concentration in fish gills to $\mathrm{Hg}$ concentration in fish muscles (log transformed data) can be described by the regression equation $\mathrm{HgG}=-3.14+0.36 \mathrm{HgM}$.

The highest average concentration of total $\mathrm{HgM}$ was reported in fish from Czarne Sosnowickie (mean $0.0504 \mathrm{mg} \cdot \mathrm{kg}^{-1}$ ), while this was significantly lower in Dratów (mean $0.0127 \mathrm{mg} \cdot \mathrm{kg}^{-1}$ ) (MANOVA, $\mathrm{F}(8,338)=14.066, \mathrm{p}<0.001)$. The concentration of this element in the muscles of fish of the other 3 lakes is not

Table 2. Trophic group, morphological characteristics (TL, in cm; W, in g), and concentration of $\mathrm{Hg}$ in fish tissues (HgM - muscles, $\mathrm{HgG}$ - gills) (in $\mathrm{mg} \mathrm{kg}^{-1}$ ) of sampled fish from the lakes; Trophic group: NP - non-predatory fish, $\mathrm{P}$ - predatory fish, $\mathrm{N}$ - number of sampled fish; SD - standard deviation.

\begin{tabular}{|c|c|c|c|c|c|c|c|c|c|}
\hline \multirow{2}{*}{ Lake } & \multirow{2}{*}{$\begin{array}{l}\text { Trophic } \\
\text { group }\end{array}$} & \multirow{2}{*}{$\begin{array}{l}\text { No. of } \\
\text { species }\end{array}$} & \multirow{2}{*}{$\mathrm{N}$} & \multirow{2}{*}{$\frac{\mathrm{TL}}{\mathrm{Mean} \pm \mathrm{SD}}$} & \multirow{2}{*}{$\frac{\mathrm{W}}{\mathrm{Mean} \pm \mathrm{SD}}$} & \multicolumn{2}{|r|}{$\mathrm{HgM}$} & \multicolumn{2}{|r|}{$\mathrm{HgG}$} \\
\hline & & & & & & Median & Range & Median & Range \\
\hline \multirow{2}{*}{ Dratów } & $\mathrm{NP}$ & 5 & 21 & $17.32 \pm 2.42$ & $71.77 \pm 35.12$ & 0.0120 & $0.0032-0.0220$ & 0.0114 & $0.005-0.041$ \\
\hline & $\mathrm{P}$ & 1 & 1 & $36.50 \pm 0.00$ & $395.25 \pm 0.00$ & 0.0185 & $0.0185-0.0185$ & 0.0093 & $0.009-0.009$ \\
\hline \multirow{2}{*}{$\begin{array}{c}\text { Białe } \\
\text { Sosnowickie }\end{array}$} & NP & 6 & 39 & $17.55 \pm 3.24$ & $54.63 \pm 32.73$ & 0.0220 & $0.0090-0.0480$ & 0.0096 & $0.001-0.024$ \\
\hline & $\mathrm{P}$ & 2 & 5 & $19.70 \pm 2.73$ & $73.71 \pm 30.91$ & 0.0249 & $0.0210-0.0554$ & 0.0141 & $0.005-0.022$ \\
\hline \multirow{2}{*}{ Domaszne } & NP & 4 & 41 & $14.61 \pm 2.74$ & $33.45 \pm 22.45$ & 0.0211 & $0.0100-0.0453$ & 0.0108 & $0.006-0.034$ \\
\hline & $\mathrm{P}$ & 3 & 11 & $17.26 \pm 4.55$ & $51.48 \pm 44.32$ & 0.0333 & $0.0177-0.0708$ & 0.0120 & $0.002-0.018$ \\
\hline \multirow{2}{*}{ Syczyńskie } & $\mathrm{NP}$ & 2 & 22 & $16.40 \pm 1.99$ & $53.88 \pm 26.89$ & 0.0234 & $0.0143-0.0400$ & 0.0091 & $0.006-0.016$ \\
\hline & $\mathrm{P}$ & 2 & 2 & $23.80 \pm 8.77$ & $124.72 \pm 86.06$ & 0.0385 & $0.0325-0.0445$ & 0.0118 & $0.008-0.016$ \\
\hline \multirow{2}{*}{$\begin{array}{c}\text { Czarne } \\
\text { Sosnowickie }\end{array}$} & NP & 4 & 31 & $16.43 \pm 2.65$ & $46.04 \pm 34.27$ & 0.0460 & $0.0267-0.0900$ & 0.0222 & $0.007-0.043$ \\
\hline & $\mathrm{P}$ & 3 & 7 & $22.28 \pm 6.00$ & $154.70 \pm 108.22$ & 0.0566 & $0.0325-0.0816$ & 0.0246 & $0.018-0.030$ \\
\hline
\end{tabular}




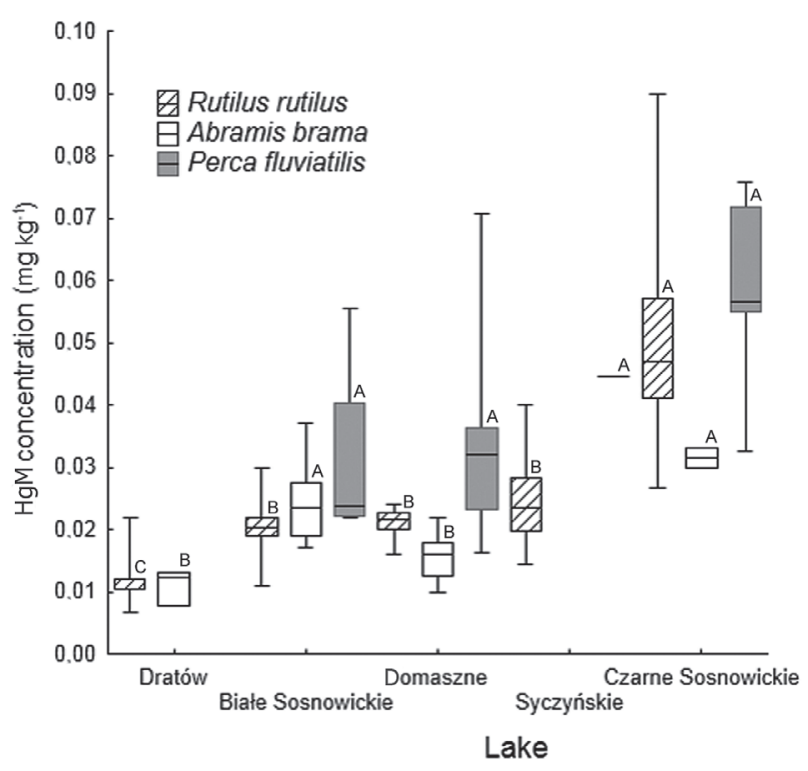

Fig. 2. The mercury concentration in muscles $\left(\mathrm{HgM}\right.$, in $\left.\mathrm{mg} \cdot \mathrm{kg}^{-1}\right)$ in dominant fish species in studied lakes, explanation of graphics: whiskers - minimal and maximal values, line - mean value, box - standard error. The other letter on particular species bar-differences statistically significant.

significantly different and ranged from $0.0249 \mathrm{mg} \cdot \mathrm{kg}^{-1}$ in Białe Sosnowickie to $0.0255 \mathrm{mg} \cdot \mathrm{kg}^{-1}$ in fish muscles from Domaszne. The concentration of $\mathrm{Hg}$ in gills was less variable and we found significantly higher concentrations only in fish from Czarne Sosnowickie (MANOVA, $\mathrm{F}(8,338)=14.066, \mathrm{p}<0.001$; Table 2$)$. The concentration of $\mathrm{Hg}$ in muscles was widely varied depending on the fish species, and its highest concentration was observed in the predatory fish such as asp and perch (MANOVA, Wilks lambda $=0.647, \mathrm{~F}(20,336)=4.0897, \mathrm{p}<0.001)$, while the lowest concentrations of this element were found in Prussian carp, bream, and rudd (Table 3). Statistical analysis showed that the concentration of $\mathrm{Hg}$ in the gills of the different fish species were not statistically different between each other. The highest concentrations were found in gills of pikeperch, roach, and asp, and the lowest in brown bullhead, pike, and Prussian carp (Table 3). Regression analysis of $\mathrm{Hg}$ concentration depending on the total length of fish (TL) showed that only in the perch was there a significant increase in the concentration of $\mathrm{Hg}$ in both tissues with increasing total length. In addition, a significant decrease of $\mathrm{HgG}$ with increasing total length was reported in roach (Table 3). From among fish species present in most of the studied lakes the roach and bream had significant differences of value of $\mathrm{HgM}$ between the lakes (MANOVA, for roach Wilks lambda $=0.111, \mathrm{~F}(8,132)=33,00, \mathrm{p}<0.001$; for bream: Wilks lambda $=0.111, F(6,48)=7.52, p=0.001)$ (Fig. 2), whereas for roach and perch the concentrations of $\mathrm{Hg}$ in gills were significantly higher only in Czarne Sosnowickie.

\section{Concentrations of $\mathrm{Hg}$ in Fish vs. Trophic Group and Size Structure}

Comparison of $\mathrm{Hg}$ concentrations in the muscles of fish by trophic groups showed that the predatory fish had significantly higher concentrations of this element in the muscles $\left(\mathrm{N}=26\right.$, mean $\left.0.0400 \mathrm{mg} \cdot \mathrm{kg}^{-1}\right)$ than nonpredatory fish $\left(\mathrm{N}=154\right.$, mean $\left.0.0272 \mathrm{mg} \cdot \mathrm{kg}^{-1}\right)$ (ANOVA, $\mathrm{F}=16.318, \mathrm{df}(1,178), \mathrm{p}=0.0019)$, whereas those trophic groups did not differ in terms of the concentration of $\mathrm{Hg}$ in the gills and it amounted to 0.0148 and $0.0132 \mathrm{mg} \cdot \mathrm{kg}^{-1}$, respectively (ANOVA, $\mathrm{F}=0.839$, df $(1,178), \mathrm{p}=0.361)$. Analysis of $\mathrm{Hg}$ concentrations in both tissues in fish from groups that differ in size class $(\mathrm{TL}<20$ and $\mathrm{TL}>20 \mathrm{~cm})$ showed that they did not differ statistically $(p>0.05)$. Slightly higher concentrations of $\mathrm{Hg}$ were observed in the muscles of fish with $\mathrm{TL}>20 \mathrm{~cm}$ (mean $0.031 \mathrm{mg} \cdot \mathrm{kg}^{-1}$ ) than in muscles of smaller fish $\left(\mathrm{TL}<20 \mathrm{~cm}\right.$, mean $\left.0.029 \mathrm{mg} \cdot \mathrm{kg}^{-1}\right)$, whereas this group of fish had a higher concentration of $\mathrm{Hg}$ in gills (mean $0.0348 \mathrm{mg} \cdot \mathrm{kg}^{-1}$ ). Regression analysis showed that the concentration of $\mathrm{Hg}$ in muscles as well as gills of non-predatory fish decreased with increasing total length of the fish. But in the case of $\mathrm{HgG}$ this decrease was statistically significant $(\mathrm{HgG}(\log )=-2.00-0.89 \mathrm{TL}(\log ) ; \mathrm{p}<0.001)$, whereas in the predatory fish group the concentration of $\mathrm{Hg}$ in tissues increased with increased total length (not statistically significant). Analysis of changes of concentrations of $\mathrm{Hg}$ in the tissues depending on the class size of fish showed that for individuals with a total length up to $20 \mathrm{~cm}, \mathrm{Hg}$ concentration showed a decreasing trend with increasing length of fish (in the case of gills on borderline of significance, i.e., $\mathrm{HgG}(\log )=-2.65-0.66 \mathrm{TL}(\log )$; $\mathrm{p}=0.047)$, whereas in large fish $(\mathrm{TL}>20 \mathrm{~cm}) \mathrm{Hg}$ concentration in tissues increased with increasing length of the fish, but was statistically significant only in the case of muscle $(\operatorname{HgM}(\log )=-8.31+1.48 \mathrm{TL}(\log ) ; \mathrm{p}=0.03)$.

\section{Hg Concentrations in Fish vs. Physical and Chemical Parameters of Water}

The direct relationships between $\mathrm{Hg}$ concentrations in fish tissues were specified using redundancy analysis (RDA). The concentration of $\mathrm{Hg}$ in fish tissues was affected by 4 variables, including $\mathrm{N}^{-\mathrm{NH}_{4}}$ $\left(\lambda_{\mathrm{a}}=0.16, F=17.92, \mathrm{P}=0.002\right)$, chl $a\left(\lambda_{\mathrm{a}}=0.12\right.$, $F=14.72, \mathrm{P}=0.029)$, oxygen saturation $\left(\lambda_{\mathrm{a}}^{\mathrm{a}}=0.04\right.$, $F=5.49, \mathrm{P}=0.035)$, and temperature $\left(\lambda_{\mathrm{a}}=0.07, F=9.90\right.$, $\mathrm{P}=0.04$ ), and the first two axes explained $78.9 \%$ of total variance in $\mathrm{Hg}$ concentration. $\mathrm{N}^{-\mathrm{NH}_{4}}$ correlated to $\mathrm{Hg}$ concentration in tissues of Rutilus rutilus and Scardinius erythrophthalmus, and chl- $a$ affected $\mathrm{Hg}$ concentration in Ameiurus nebulosus, Alburnus alburnus, and Carassius gibelio, whereas oxygen saturation was related to $\mathrm{Hg}$ concentration in Abramis brama. Temperature showed no clear relationship to $\mathrm{Hg}$ concentration of any species 


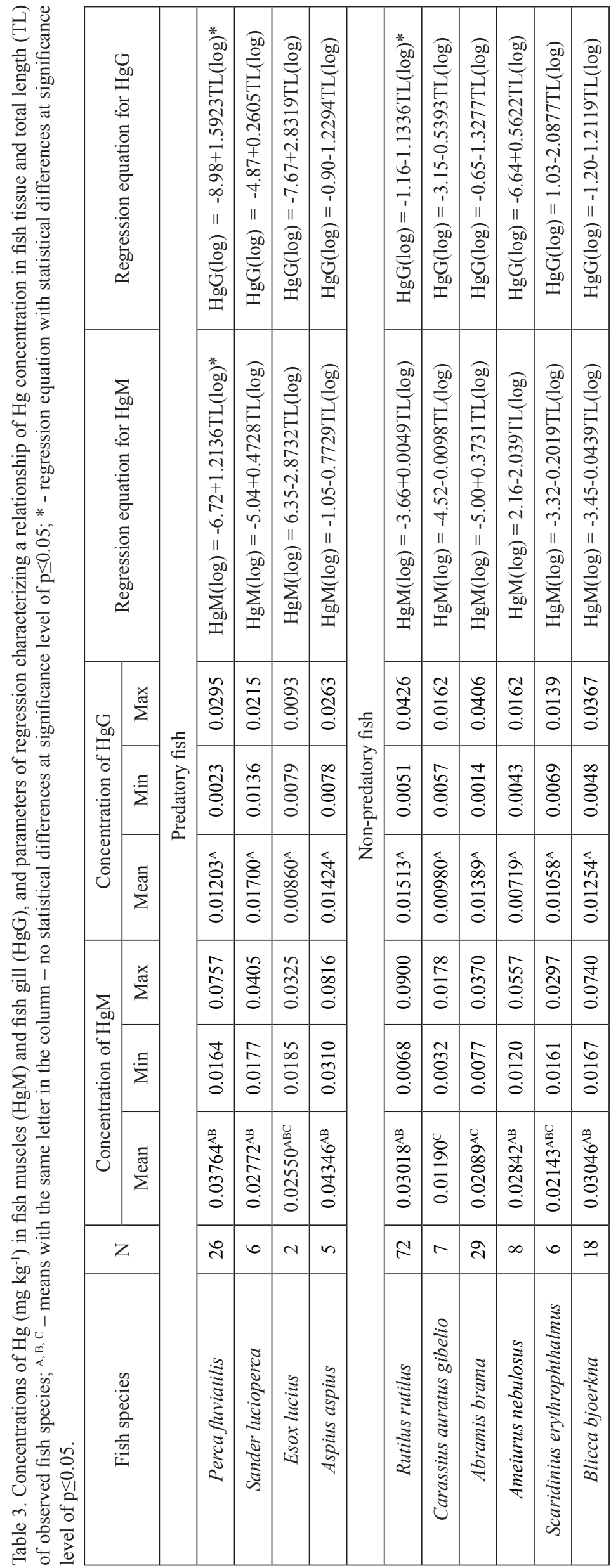



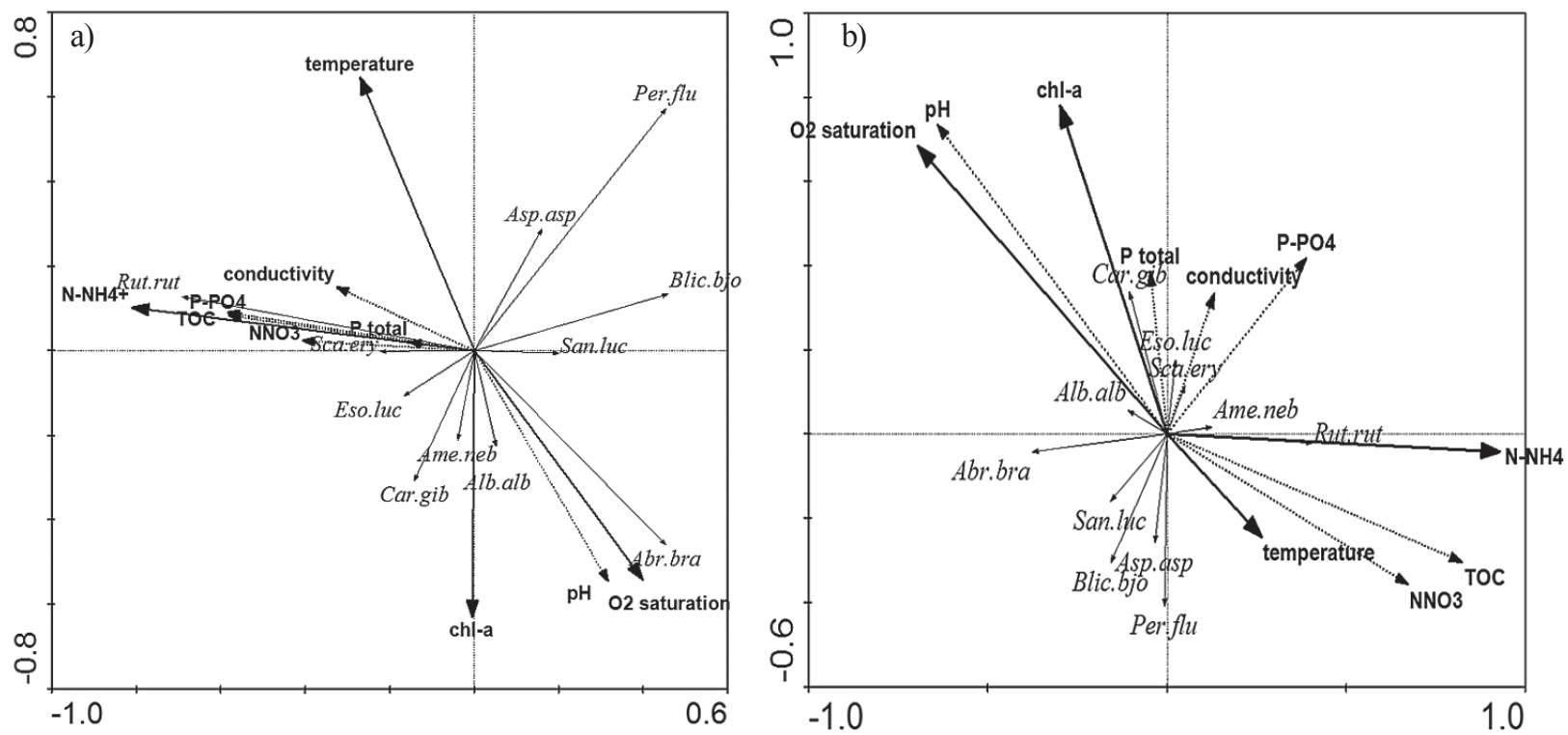

Fig. 3. Redundancy analysis biplot for fish assemblages showing mercury concentration in tissues (muscles a) and gills b) and environmental variables. Species codes: Rut.rut. - Rutilus rutilus, Car.gib - Carassius gibelio, Abr.bra - Abramis brama, Ame.neb Ameiurus nebulosus, Eso.luc - Esox lucius, Blic.bjo - Blicca bjoerkna, San.luc - Sander lucioperca, Alb.alb - Alburnus alburnus, Per. flu-Perca fluviatilis, Sca.ery - Scardinius erythrophthalmus, Asp.asp-Aspius aspius.

(Fig. 3a). The same variables, namely $\mathrm{N}-\mathrm{NH}_{4}\left(\lambda_{\mathrm{a}}=0.21\right.$, $F=11.00, \mathrm{P}=0.002)$, chl- $a\left(\lambda_{\mathrm{a}}=0.17, F=9.60, \mathrm{P}=0.028\right)$, oxygen saturation $\left(\lambda_{\mathrm{a}}=0.09, F=7.03, \mathrm{P}=0.037\right)$, and temperature $\left(\lambda_{\mathrm{a}}=0.07, F=2.54, \mathrm{P}=0.042\right)$ affected the concentration of $\mathrm{Hg}$ in gills. Although the first two axes explained $60.9 \%$ of total variance in $\mathrm{Hg}$ concentration, distribution of environmental variables and species on RDA biplot suggest that environmental variables equally influenced the concentration of $\mathrm{Hg}$ in gills for all species (Fig. 3b).

\section{Discussion}

Trophic Status and Physical and Chemical Parameters of Lakes vs. Hg Concentrations in Fish

Our study showed that the $\mathrm{Hg}$ concentration in the fish tissues varied depending on the lake and on the species, size, and food preferences of the fish. The study contributes to the attempts made in recent years to find links between $\mathrm{Hg}$ in the tissues of fish or other organisms from the aquatic ecosystem and the physicochemical parameters of the water or trophic relationships between organisms [27-28]. However, it has been proven difficult to find a model showing changes in the content of this element at different levels of the trophic pyramid or in fish [29], and as reported by [2], analysis of a dozen or so lake ecosystems in Canada indicates that the content of $\mathrm{Hg}$ in fish tissues is often closely dependent on the lake itself. The present study found relatively high variation in $\mathrm{Hg}$ content in fish tissues depending on the concentration of chlorophyll $a$ in the water, as $\mathrm{Hg}$ concentration in the fish from the lakes tested was found to decrease as the concentration of chlorophyll $a$ in the water increased (Fig. 1). A similar negative correlation between $\mathrm{Hg}$ accumulation and chlorophyll a concentration has been found in some species of fish in North America (largemouth bass Micropterus salmoides, smallmouth bass Micropterus dolomieu, walleye Sander vitreus, and yellow perch Perca flavescens) [30], and in many species of fish in African lakes [19].

Physicochemical conditions and parameters characterizing the level of eutrophication influence the specific character of trophic levels and the productivity of lakes. Kidd et al. [29] noted the highest $\mathrm{Hg}$ concentration in the food web in large, highly productive lakes. According to Pickhardt et al. [31] and Clayden et al. [2], in eutrophic lakes the concentration of $\mathrm{Hg}$ in plankton, zooplankton, and fish was lower than in oligotrophic lakes. The productivity of water bodies appears to be a key factor, since increased plankton density accompanied by greater plankton biomass caused a decrease in total $\mathrm{Hg}$ concentration in this element of the food web. In contrast, Chen and Folt [17] report that lower productivity in lakes and lower plankton density led to greater transfer of $\mathrm{Hg}$ to fish. This is confirmed by studies by Kidd et al. [10] and Chen et al. [18], in which higher $\mathrm{Hg}$ concentration was found in the fish of lakes with lower productivity. Contrasting results, i.e., low $\mathrm{Hg}$ content in fish, were obtained by Yan et al. [32] in the hypertrophic Lake Taihu and by Cheng et al. [33] in aquaculture ponds with higher productivity. On the other hand, the complexity of the phenomenon was demonstrated by Chen and Folt [17], who found similar $\mathrm{Hg}$ values in the tissues of 2 species, trout and bullies, from lakes with different trophic status. 
Analysis of our results showed that in the shallow lakes studied in the temperate zone, the parameters affecting the concentration of $\mathrm{Hg}$ in the analysed fish tissues, apart from chlorophyll $a$ and $\mathrm{N}_{-} \mathrm{NH}_{4}$ concentrations, included oxygen saturation and temperature. It should be emphasized that the effect of these parameters on the $\mathrm{Hg}$ accumulated in the gills was somewhat less pronounced. The significance of other water parameters on $\mathrm{Hg}$ concentration in the food web or in organisms has been a subject of discussion in recent years and has not been clearly established. However, as noted by McMurtry et al. [34], analysis of fish from Lake Ontario indicates that the best prognostic factor may be dissolved organic carbon (DOC). Lower $\mathrm{Hg}$ concentration in fish in lakes with lower DOC has also been observed by Gilmour et al. [35] in the northern Everglades. According to Pollman [36], this parameter is a key factor and should be taken into account in models simulating $\mathrm{Hg}$ circulation in the ecosystem. On the other hand, a study by Simonin et al. [30] showed that this parameter did not significantly affect the content of $\mathrm{Hg}$ in the tissues of yellow perch and bass.

\section{Fish Species, Size, and Food Preferences vs. $\mathrm{Hg}$ Concentrations in Fish Tissues}

Our observations showed that $\mathrm{Hg}$ content varied depending on the species of fish, and was markedly higher in predatory species such as asp and perch. However, significant differences were noted only in the case of $\mathrm{Hg}$ concentration in the muscles (Table 3 ). The accumulation of greater quantities of $\mathrm{Hg}$ in predatory fish has been observed in recent years by researchers such as Moreno et al. [37], and is linked to the trophic level occupied by these species (top-predators) [9, 38]. However, these authors state that this is not a rule, as this relationship was not confirmed in the case of yellowfin tuna. Further observations are undoubtedly needed, but it is a fact that the main source of $\mathrm{Hg}$ in fish is their food [9]. The effect of diet on $\mathrm{Hg}$ concentrations in walleye was studied by Johnson et al. [25], whose observations showed that concentrations in individual fish fed on invertebrates was almost 10 times lower than in fish fed on fish. In our study, the lowest $\mathrm{Hg}$ concentrations in the tissues were also noted in non-predatory species (Prussian carp, bream and rudd) (Tables 2 and 3).

$\mathrm{Hg}$ concentration was also found to vary considerably between the tissue types analysed. Markedly lower concentrations were noted in the gills than in the muscles (Table 3). Studies by some authors have shown that the skin and gills serve as a medium by which $\mathrm{Hg}$ passes from the environment (water, substrate, sediment, etc.) to other tissues [9], while it is mainly accumulated in the muscles and liver [23, 39].

The available literature indicates that $\mathrm{Hg}$ concentration increases with the age and size of fish [23, 39-41]. The same tendency was observed in our study in all species of fish, irrespective of the trophic status of the lake (Fig. 1), but the increase was statistically significant only in the case of perch (Table 3). According to Sonesten [24], perch is one of the species that can be treated as a model species for determining $\mathrm{Hg}$ concentration vs. fish-size dependence. Of course this is possible when we have an adequate number of samples with a wide range of individual total lengths. On the other hand, Liu et al. [39] found a negative correlation between $\mathrm{Hg}$ concentration in tissues and fish size in sea bass. Similarly, Moreno et al. [37] found no correlation in whitefish in different seasons of the year. Sonesten [24] suggest that this may also be due to numerous environmental factors, including lake $\mathrm{pH}$, specific conductivity, and concentrations of chlorophyll $a$ and $\mathrm{Hg}$ in the water. According to Stafford and Haines [42], analyses are usually based on a small, limited number of samples; hence the correlation between $\mathrm{Hg}$ content and fish size cannot always be treated as a rule. In our observations this was visible in the case of roach, in which $\mathrm{Hg}$ content in the gills decreased substantially as body length increased. It is possible that in the case of individuals with small dimensions and biomass the relative concentration of $\mathrm{Hg}$ may be greater than in larger individuals.

\section{Potential Impact on Human Health}

An extremely important issue is the use of fish from the investigated lakes as food. According to Commission Regulations (EC) [43-44], the level of $\mathrm{Hg}$ for most fish should not exceed $500 \mu \mathrm{g} \cdot \mathrm{kg}^{-1}$, while in the case of certain predatory species, e.g., pike, a level of $\mathrm{Hg}$ contamination of up to $1,000 \mu \mathrm{g} \cdot \mathrm{kg}^{-1}$ is permitted [44]. The $\mathrm{Hg}$ concentrations found in the fish muscles in our study should be regarded as low. In all of the muscle samples analysed, from both predatory and nonpredatory fish, the content of this element was well below the permissible limits.

The fact that intake of even trace amounts of $\mathrm{Hg}$ poses a health risk, while the use of fish as food is a tradition in the area studied, raises the question of whether and to what degree the presence of $\mathrm{Hg}$ in the tissues of consumed fish may harm the local population. The potential risk is associated not only with the quantity of $\mathrm{Hg}$, but primarily with the form in which it is consumed. According to Sedláčková et al. [45], nearly all of the $\mathrm{Hg}$ contained in fish occurs in its most toxic form, i.e., methyl Hg. Our previous studies (unpublished) revealed that in fish from lakes from the examined area methyl $\mathrm{Hg}$ concentrations amounted to $67.5 \%$ and $86.5 \%$ of the total $\mathrm{Hg}$ in non-predators and predators, respectively. The provisional tolerable weekly intake (PTWI) of methyl $\mathrm{Hg}$ compounds from all sources for a healthy person has been established by the Joint FAO/WHO Expert Committee on Food Additives (JECFA) as $1.3 \mu \mathrm{g} \cdot \mathrm{kg}^{-1}$ body weight, i.e., $112 \mu \mathrm{g}$ for a person weighing $70 \mathrm{~kg}$ [46-47]. Assuming the highest level of contamination found in the muscles of fish in our study $\left(0.09 \mathrm{mg} \cdot \mathrm{kg}^{-1}\right)$, consumption of $1 \mathrm{~kg}$ of fish a week would mean intake of $90 \mu \mathrm{g}$ of $\mathrm{Hg}$ a week, or $80 \%$ of the PTWI for methyl $\mathrm{Hg}$. Consumption of fish from monitored sites is safe for 
the moderate consumer. However, given that the PTWI index must take into account all of the $\mathrm{Hg}$ entering the body from all sources (e.g., air, water, or food additives), consumption of large quantities of fish may raise concerns regarding toxicity.

\section{Conclusions}

In conclusion, our study found variations in $\mathrm{Hg}$ content in fish depending on the lake and the species. In addition, $\mathrm{Hg}$ concentration in the tissues was inversely correlated with the level of chlorophyll $a$ in the lakes. Content of $\mathrm{Hg}$ in the tissues was markedly higher in predatory fish, and increased with their body length. In non-predatory fish this correlation was less clear. The gills of the fish contained lower concentrations of $\mathrm{Hg}$ than the muscles, but the level showed similar tendencies as in the case of the muscle tissue, though it was less dependent on the physicochemical parameters of the water in the lakes. Although the $\mathrm{Hg}$ content in the fish from the lakes was substantially lower than the acceptable limits, the fish could pose a potential health risk if consumed in large quantities by the local population.

\section{Conflict of Interest}

The authors declare no conflict of interest.

\section{References}

1. HEDAYATI A., SAFAHIEH A. Serum hormone and biochemical activity as biomarkers of $\mathrm{Hg}$ toxicity in the yellowfin seabream Acanthopagrus latus. Toxicol. Ind. Health. 28, 306, 2012.

2. CLAYDEN M.G., KIDD K.A., WYN B., KIRK J.L., MUIR D.C.G., O'DRISCOLL N.J. Hg Biomagnification through Food Webs Is Affected by Physical and Chemical Characteristics of Lakes. Environ. Sci. Technol. 47, 12047, 2013.

3. PACK E.C., LEE S.H., KIM C.H., LIM C.H., SUNG D.G., KIM M.H., PARK K.H., LIM K.M., CHOI D.W., KIM S.W. Effects of Environmental Temperature Change on $\mathrm{Hg}$ Absorption in Aquatic Organisms with Respect to Climate Warming. J. Toxicol. Environ. Health A. 77, 1477, 2014.

4. RAZAVI N.R., ARTS M.T., QU M., JIN B., REN W., WANG Y., CAMPBELL L.M. Effect of eutrophication on selenium, and essential fatty acids in bighead carp (Hypophthalmichthys nobilis) from reservoirs of eastern China. Sci. Total Environ. 15, 36, 2014.

5. CHÉTELAT J., AMYOT M., ARP P., BLAIS J.M., DEPEW D., EMMERTON C.A., EVANS M., GAMBERG M., GANTNER N., GIRARD C., GRAYDON J., KIRK J., LEAN D., LEHNHERR I., MUIR D., NASR M., POULAIN A.J., POWER M., ROACH P., STERN G., SWANSON H., VAN DER VELDEN S.H. Hg in freshwater ecosystems of the Canadian Arctic: Recent advances on its cycling and fate. Sci Total Environ. 510, 41, 2015.

6. KAYA G., TURKOGLU S. Bioacumulation of heavy metals in various tissues of some fish species and green tiger shrimp (Penaeus semisulcatus) from Iskenderun Bay, Turkey, and risk assessment from human health. Biol. Trace Elem. Res. 180, 314, 2017.

7. LESCORD G.L., KIDD K.A., KIRK J.L., O'DRISCOLL N.J., WANG X., MUIR D.C.G. Factors affecting biotic $\mathrm{Hg}$ concentrations and biomagnification through lake food webs in the Canadian high Arctic. Sci. Total Environ. 510, 195, 2015.

8. WAŁKUSKA G., CHAŁABIS-MAZUREK A., SZKODA $\mathrm{J} . \mathrm{Hg}$ content in the trophic chain of the Tanew River, Poland, ecosystem. J. Toxicol. Environ. Health A. 73, 1180, 2010.

9. HALL B.D., BODALY R.A., FUDGE R.J.P., RUDD J.W.M., ROSENBERG D.M. Food as the dominant pathway of methylHg uptake by fish. Water Air. Soil Pollut. 100, 13, 1997.

10. KIDD K.A., BATCHELAR K. Hg. In: WOOD C.M., FARRELL A.P., BRAUNER C.J. (eds) Homeostasis and toxicology of non-essential metals (Fish Physiology vol. 31b), Elsevier Press, Amsterdam, 2011.

11. KIDD K.A., MUIR D.C.G., EVANS M.S., WANG X., WHITTLE M., SWANSON H.K., JOHNSTON T., GUILDFORD S. Biomagnification of $\mathrm{Hg}$ through lake trout (Salvelinus namaycush) food webs of lakes with different physical, chemical and biological characteristics. Sci. Total Environ. 438, 135, 2012.

12. MILLER A., BIGNERT A., PORVARI P., DANIELSSON S., VERTA M. Hg in Perch (Perca fluviatilis) from Sweden and Finland. Water Air Soil Poll. 224, 1472, 2013.

13. ØKELSRUD A., LYDERSEN E., FJELD E. Biomagnification of $\mathrm{Hg}$ and selenium in two lakes in southern Norway. Sci. Total Environ. 566 - 567, 596, 2016.

14. ØKELSRUD A., LYDERSEN E., MORENO C., FJELD E. $\mathrm{Hg}$ and selenium in free-ranging brown trout (Salmo trutta) in the River Skienselva watercourse, Southern Norway. Sci. Total Environ. 586, 188, 2017.

15. BOSCH A.C., O'NEILL B., SIGGE G. O. KERWATH S.E., HOFFMAN L.C. Hg accumulation in Yellowfin tuna (Thunnus albacares) with regards to muscle type, muscle position and fish size. Food Chem. 190, 351, 2016.

16. BURGER J., GOCHFELD M. Hg and selenium levels in 19 species of saltwater fish from New Jersey as a function of species, size, and season. Sci. Total Environ. 409, 1418, 2011.

17. CHEN C.Y., FOLT C. High plankton densities reduce $\mathrm{Hg}$ biomagnification. Environ. Sci. Technol. 39, 115, 2005.

18. CHEN C.Y., STEMBERGER R.S., KAMMAN N.C., MAYES B.M., FOLT C.L. Patterns of Hg bioaccumulation and transfer in aquatic food webs across multi-lake studies in the northeast US. Ecotoxicology 14, 135, 2005.

19. POSTE A.E., MUIR D.C.G., GUILDFORD S.J., HECKY R.E. Bioaccumulation and biomagnification of $\mathrm{Hg}$ in African lakes: The importance of trophic status. Sci. Total Environ. 507, 126, 2015.

20. CHALMERS A.T., ARGUE D.M., GAY D.A., BRIGHAM M.E., SCHMITT C.J., LORENZ D.L. Hg trends in fish from rivers and lakes in the United States, 1969-2005. Environ. Monit. Assess. 175, 175, 2011.

21. HANNA D. E. L., BUCK D. G., CHAPMAN L. J. Effects of habitat on $\mathrm{Hg}$ concentrations in fish: a case study of Nile perch (Lates niloticus) in Lake Nabugabo, Uganda. Ecotoxicology. 25 (1), 178, 2016.

22. JIRSA F., PIRKER D., KRACHLER R., KEPPLER B.K. Total Hg in Sediments, Macrophytes, and Fish from a Shallow Steppe Lake in Eastern Austria. Chem. Biodivers. 11, 1263, 2014. 
23. FARKAS A., SALÄNKI J., SPECZIÁR A. Age- and sizespecific patterns of heavy metals in the organs of freshwater fish Abramis brama L. populating a low-contaminated site. Water Res. 37 (5), 959, 2003.

24. SONESTEN L. Fish $\mathrm{Hg}$ levels in lakes-adjusting for $\mathrm{Hg}$ and fish-size covariation. Environ. Pollut. 125, 255, 2003.

25. JOHNSON B.M., LEPAK J.M., WOLFF B.A. Effects of prey assemblage on $\mathrm{Hg}$ bioaccumulation in a piscivorous sport fish. Sci. Total Environ. 507, 330, 2015.

26. DOWNS S.G., MACLEOD C.L., LESTER J.N. Hg in precipitation and its relation to bioaccumulation in fish. Water Air. Soil Pollut. 108, 149, 1998.

27. GANTNER N., POWER M., IQALUK D., MEILI M., BORG H., SUNDBOM M., SOLOMON K.R., LAWSON G., MUIR D.C. Hg concentrations in landlocked Arctic char (Salvelinus alpinus) from the Canadian Arctic. Part I: insights from trophic relationships in 18 lakes. Environ. Toxicol. Chem. 29, 621, 2010.

28. ROLFHUS K.R., HALL B.D., MONSON B.A., PATERSON M.J., JEREMIASON J.D. Assessment of $\mathrm{Hg}$ bioaccumulation within the pelagic food web of lakes in the western Great Lakes region. Ecotoxicology. 20, 1520, 2011.

29. KIDD K.A., PATERSON M.A., HESSLEIN R.H., MUIR D.C.G., HECKY R.E. Effects of northern pike (Esox lucius) additions on pollutant accumulation and foodweb structure, as determined by $\delta 13 \mathrm{C}$ and $\delta 15 \mathrm{~N}$, in a eutrophic and an oligotrophic lake. Can J. Fish. Aquat. Sci. 56, 2193, 1999.

30. SIMONIN H.A., LOUKMAS J.J., SKINNER L.C., ROY K.M. Lake variability: Key factors controlling $\mathrm{Hg}$ concentrations in New York State fish. Environ. Pollut. 154, 107, 2008.

31. PICKHARDT P.C., FOLT C.L., CHEN C.Y., KLAUE B., BLUM J.D. Algal blooms reduce the uptake of toxic methylHg in freshwater food webs. Proc. Natl. Acad. Sci. USA 99, 4419, 2002.

32. YAN H., RUSTADBAKKEN A., YAO H., LARSSEN T., FENG X., LIU T., SHANG L., HAUGEN T.O. Total Hg in wild fish in Guizhou reservoirs, China. J. Environ. Sci. 22, 1129, 2010.

33. CHENG Z., LIANG P., SHAO D., WU S., NIE X., CHEN K., LI K., WONG M. Hg biomagnification in the aquaculture pond ecosystem in the Pearl River Delta. Arch. Environ. Contam. Toxicol. 61, 491, 2011.

34. MCMURTRY M.J., WALES K.L., SCHEIDER W.A., BEGGS G.L., DIMOND P.E. Relationship of $\mathrm{Hg}$ concentrations in lake trout (Salvelinus namaycush) and smallmouth bass (Micropterus dolomieu) to the physical and chemical characteristics of Ontario lakes. Can. J. Fish. Aquat. Sci. 46, 426, 1989.
35. GILMOUR C.C., RIEDEL G.S., EDERINGTON M.C., BELL J.T., BENOIT J.M., GILL G.A., STORDAL M.C. MethylHg concentrations and production rates across a trophic gradient in the northern Everglades. Biogeochemistry. 40, 327, 1998.

36. POLLMAN C.D. Hg cycling in aquatic ecosystems and trophic state-related variables - Implications from structural equation modeling. Sci. Total Environ. 499, 62, 2014.

37. MORENO C.E., FJELD E., DESHAR M.K., LYDERSEN E. Seasonal variation of $\mathrm{Hg}$ and $\delta 15 \mathrm{~N}$ in fish from Lake Heddalsvatn, southern Norway. J. Limnol. 74 (1), 21, 2015.

38. WYN B., KIDD K.A., BURGESS N.M., CURRY R.A. $\mathrm{Hg}$ biomagnification in the food webs of acidic lakes in Kejimkujik National Park and National Historic Site, Nova Scotia. Can. J. Fish. Aquat. Sci. 66, 1532, 2009.

39. LIU J., CAO L., HUANG W., DOU S. Species- and tissue-specific $\mathrm{Hg}$ bioaccumulation in five fish species from Laizhou Bay in the Bohai Sea of China. Chinese J. Oceanol. Limnol. 31 (3), 504, 2013.

40. GONUL L.T., KUCUKSEZGIN F. Hg accumulation and speciation in the muscle of red mullet (Mullus barbatus) and annular sea bream (Diplodus annularis) from Izmir Bay (Eastern Aegean). Mar. Pollut. Bull. 54 (12), 1962, 2007.

41. LAVIGNE M., LUCOTTE M., PAQUET S. Relationship between $\mathrm{Hg}$ concentration and growth rates for walleyes, northern pike, and lake trout from Quebec lakes. N. Am. J. Fish. Manag. 30 (5), 1221, 2010.

42. STAFFORD C.P., HAINES T.A. Hg contamination and growth rate in two piscivore populations. Environ. Toxicol. Chem. 20, 2099, 2001.

43. EC - European Commission Regulation No. 629/2008 of 2 July 2008 amending Regulation (EC) No 1881/2006 setting maximum levels for certain contaminants in foodstuffs (OJ UE, L 173/6, 3.07.2008).

44. EC - European Commission Regulation No. 420/2011 amending Regulation (EC) No. 1881/2006 setting maximum levels for certain contaminants in foodstuffs. (OJ UE, L 111, 30.04.2011).

45. SEDLÁČKOVÁ L., KRUŽÍKOVÁ K., SVOBODOVÁ Z. $\mathrm{Hg}$ speciation in fish muscles from major Czech rivers and assessment of health risks. Food Chem. 150, 360, 2014.

46. Joint FAO/WHO Expert Committee on Food Additives, Seventy-second meeting. Summary and Conclusions. Rome 16-25 February, 2010.

47. WORLD HEALTH ORGANIZATION (WHO). Evaluation of certain contaminants in food. WHO Technical Report Series, No 959. 2011. 